\title{
A BELGIAN FLAT INCOME TAX: EFFECTS ON LABOUR SUPPLY AND INCOME DISTRIBUTION
}

\author{
ANDRÉ DECOSTER \\ KRIS DE SWERDT \\ KRISTIAN ORSINI \\ Centre For Economic Studies - Leuven ${ }^{(*)}$
}

August 2008

\begin{abstract}
The adverse distributional effects of a flat tax are well known and have been documented by empirical research in several countries, including Belgium. Advocates of the flat tax argue, correctly, that these studies do not take into account agents' behavioural reactions and possible feed back effects. One of the important effects in this context is the potential increase in labour supply and the resulting increase in the taxable base and decrease in unemployment allowances. In this study we calculate the cost recovery based on a micro-simulation model that includes a labour supply model.

We find that there is indeed a clearly positive effect on labour supply and hence also on the tax base. By introducing a revenue-neutral flat tax, labour supply increases by approximately 47,000 full-time equivalents. However, the effect is limited because, compared to a static scenario the cost recovery only allows the revenue-neutral flat tax to decrease from $38.5 \%$ to $37 \%$. Furthermore, there is little or no impact of these employment effects on the strongly regressive nature of a flat tax reform.
\end{abstract}

\footnotetext{
Correspondence: André Decoster, Centre for Economic Studies, Naamsestraat 69, 3000 Leuven; andre.decoster@econ.kuleuven.be; tel.: +32 16 326823. The authors are grateful to Daniela Mantovani for invaluable help with the preparation of the Belgian budget survey data for use in EUROMOD and to Guy Van Camp for remarks on an earlier version of this paper. Of course, none of them can be held responsible for any reamining errors. In particular, this applies to the interpretation of EUROMOD model results and any errors in its use.
} 


\section{INTRODUCTION}

Decoster and Van Camp (2005) have outlined the distributional effects of introducing a flat tax in Belgium by means of simulations on a representative sample of 22,731 tax returns with taxable incomes from 2001 (and thus taxed according to the system in force in 2002). Two conclusions can be drawn from their results. First, the $a$ priori expectations that a flat tax undermines the progressiveness of the personal income tax were confirmed. The lowest incomes lose while the higher incomes gain. A revenue-neutral flat tax, with only a basic exemption at the bottom, leads to an $8 \%$ to $10 \%$ loss of disposable income for families in the second to fourth deciles, and to a gain of $7 \%$ for those in the top decile. Even in the most "progressive" scenario, namely maintaining the tax reduction for replacement incomes, the effect of the flat tax remained regressive. In short, contrary to what is often heard in the popular debate, the current personal income tax in effect still redistributes from rich to poor. Recent studies for Belgium (Valenduc, 2006), for the United Kingdom (Adam and Brown, 2006), for Germany (Fuest, Peichl and Schaefer, 2008), for the Netherlands (Jacobs, de Mooij and Folmer 2007) and for several European countries (Paulus and Peichl, 2008) confirm these results. ${ }^{1}$

The second conclusion in Decoster and Van Camp (2005) is that, to be revenue neutral, the flat tax must be in the order of 35 to $40 \%$, depending on the specific scenario. In particular - and not surprisingly - the maintenance and the amount of the basic exemption levels played an important role in this result. With a purely proportional tax, a rate of only $23.5 \%$ was needed to obtain revenue neutrality. However, the introduction of basic exemptions drove the tax rate up to $34.1 \%$. If the tax credits for replacement incomes were also maintained, the rate even rose to $39.5 \%$. One of the conclusions in Decoster and Van Camp (2005) is therefore that proposals for introducing a flat tax of $20 \%$ or $25 \%$ in Belgium are either ill-considered ${ }^{2}$ or based on one or more of the following presumptions: 1) the introduction of significant compensating increases in other taxes (e.g. indirect taxes); 2) unrealistically large spending cuts; or 3) substantial cost recovery effects resulting in a budgetary cost of, for instance, a $25 \%$ flat tax that is much lower than estimated when no behavioural effects are taken into account.

Indeed, the impossibility to estimate these behavioural reactions was one of the limitations of the previous study. As the following quote shows, the authors were well aware of this fact:

Whether this high revenue-neutral rate of $40 \%$ renders the flat tax debates irrelevant is another issue. Our rough estimate of the marginal rates showed that more than $68 \%$

1 Valenduc (2006) describes the distributional effects of a flat tax as: "Les variations de la progressivité et de l'effet redistributif sont en fait plus proches d'un séisme que d'une réforme" (p.69).

2 For a $25 \%$ flat tax rate, we estimated the cost to be $€ 8.9$ billion in 2005 , keeping in mind that only the basic exemptions were maintained. If the reduction for replacement incomes is also introduced then a rate of $25 \%$ would raise the cost even further to $€ 12.7$ billion. 
of the fiscal families are now taxed at a marginal rate of more than $40 \%$ (Table 3). For a large majority of the fiscal families, the flat tax system leads to a potentially much higher net return from labour at the margin. This could indeed lead to an increase in the labour supply. But the literature indicates small effects as regards the increase in the number of hours (see, e.g., Aaberge et al., 1998, for a simulation of a flat tax in Italy and Ivanova et al., 2005, for an evaluation of the introduction of the flat tax in Russia in 2001). If any effect on the labour supply is to be expected it would have to be established through an increased labour-force participation rate of low-paid workers who, with the current net wages, are not joining the labour market. However, in that case the $40 \%$ rate is of course a high marginal tax rate. Therefore, tax cuts for low incomes, as introduced in the last tax reform, appear to be a much better tool. It should be pointed out that the argument of "cost recovery" reaches further than merely labour supply reactions. Tax revenue can also be increased through changes in how incomes are declared, see e.g. Feldstein (1995) for empirical evidence following the 1986 reform in the US. Another possibility is that the taxpayers find it less advantageous to evade or avoid taxes. Ivanova et al.'s (2005) study, for instance, demonstrated that the increase in tax revenue after the introduction of the flat tax in Russia did not result from an increase in labour supply but rather from less evasion. Here we leave open the question as to what extent the Russian experience may apply to Belgium.

Decoster and Van Camp (2005) [translated from Dutch], p. 23

In this paper we will attempt to fill this significant void. We estimate the effect of the introduction of a flat tax, both on the non-active who might enter the labour market and on the working population who as a result of the change in the incentives structure might work more, less or even leave the labour market. Hence, an econometric model explaining the labour supply behaviour of households is needed. This in turn requires a dataset in which we observe labour supply for individuals in households. Since this is not the case in the fiscal data used in Decoster and Van Camp (2005), in this paper we work with the budget surveys of the Belgian National Institute for Statistics (NIS). This switch from the fiscal data to the budget survey data also comes at a price: the details of the tax return, like the declared professional costs, other allowances or the direct observation of the taxable income, are lost. ${ }^{3}$ On the other hand, budget survey data contain detailed information on household expenditures that can be exploited to assess the effects on indirect tax revenues.

By taking up potential labour supply effects, the results in this paper allow to verify how much lower the revenue-neutral flat tax could be if the feedback effects are taken into account. Unfortunately, the other limitations mentioned in the above quote remain. Changes in evasion or avoidance behaviour or the shift from taxable income to other forms of declaration are not modelled. Furthermore, the labour supply model itself is a partial model. It only focuses on the supply side of the labour market, making the implicit assumption that labour demand is infinitely elastic. All of the predicted

3 For a detailed analysis of the distribution of some of these deductions through the income distribution, see Decoster and Van Camp (2005). 
expansion of labour supply will find a matching labour demand. This is clearly an oversimplification of reality, since demand side constraints (especially in some geographical regions) may counter the potential expansion of the additional labour supply. Our estimates of changes in labour supply of the cost recovery must therefore be interpreted as upper limits. ${ }^{4}$

The rest of this paper is organised as follows. The next section discusses the advantages and limitations of the dataset used, the way in which the taxes were calculated by means of a micro-simulation model and how labour supply has been modelled. In section 3 we first replicate the flat tax calculations in Decoster and Van Camp (2005) using the budget survey data. This section discusses the results of the revenue-neutral flat taxes without labour supply reactions and describes average and marginal personal income tax rates across the income distribution. These calculations serve as the reference scenario with which the results from section 4 can then be compared. Economic agents' labour supply reactions following the introduction of a flat tax are analysed in section 5 . Section 6 summarizes and concludes.

\section{DATA AND METHODOLOGY}

The "neglect" of behavioural effects in Decoster and Van Camp (2005) was due to the use of otherwise very valuable fiscal data. The Belgian fiscal data set contains taxable income and very detailed elements from the tax declaration, but no information on labour supply. Accounting for behavioural reactions therefore required working with a dataset that contains (among other things) information on whether people are active on the labour market and preferably also the number of hours they work. The budget surveys of the Belgian Statistical Institute used here contain, besides the required labour market status, a wealth of other socio-economic and expenditure data for a representative sample of Belgian households.

We made a distinction between the sample used to estimate the labour supply model, and the sample on which we simulate the effect of the tax change. For the former we wanted to have a sample as big as possible. Therefore we pooled four budget surveys: the ones of 1999, 2000, 2001 and 2002 providing us with 15001 households and 34758 individuals. For the simulation, the sample was restricted to the 2002 survey only, containing information on 3,720 households and 8,340 individuals.

Since the budget surveys only contain net or disposable household income (after taxes) and not gross income, we first used the micro-simulation model described in the next paragraph to reconstruct gross incomes from net earnings. This backward

4 We also neglect other effects further down the road, such as changes in equilibrium wages following the change in labour supply. Some of these general equilibrium effects following the introduction of a flat tax have been analysed in e.g. Ventura (1999) and Altig, Auerbach, Kotlikoff, Smetters and Walliser (2001). 
calculation was based on the fiscal and parafiscal regulations of the year of the survey itself. ${ }^{5}$

Once a representative sample with gross incomes was available, the Belgian module of the micro-simulation model EUROMOD was used to calculate the personal income tax in the baseline scenario. ${ }^{6}$ This baseline was defined as the 2005 Belgian personal income tax system. Since the simulations were performed on the 2002 survey only, with income data from 2002, we inflated all nominal income variables using the CPI between June 2002 and June 2005 (factor 1.072). This baseline scenario has then been compared with the net incomes obtained after the introduction of flat taxes. The simulations include a proportional flat tax in which also the basic exemptions are removed, and the more realistic scenario in which this basic exemption remains in place.

Removal of all other tax reductions and exemptions in practice boils down to the removal of the tax reduction for replacement incomes and of the marital quotient (or "splitting" rule ) allowing one earner households to transfer part of labour income to the non working spouse. For the calculation of other important and less important tax reductions, like those related to mortgage loans, pension saving, and so on, either there is no information in the budget survey or no calculation module in EUROMOD. The focus of this paper being on the effects of labour supply, this limitation seems not too dramatic.

The flat tax with a basic exemption level only contains two policy parameters: the exemption level and the marginal rate. Imposing budget neutrality therefore must be carried out by varying these parameters. We decided to endogenise the flat tax rate and maintain the exemption level. ${ }^{7}$ The basic exemptions are those from the reference scenario ( $€ 5,780$ per adult and $€ 1,230, € 1,930, € 3,920$ and $€ 4,370$ respectively for the first, second, third and fourth and other dependent children).

The behavioural reaction to the tax change on labour supply was modelled by means of a -by now more or less standard-discrete choice model. This relates the information on labour supply in the budget survey to explanatory variables such as the gross hourly wages, non-labour incomes, tax parameters and socio-economic characteristics of the individual and family (gender, region, level of education, etc.). The model used for estimating and predicting the labour supply is a discrete probit

5 The microsimulation model EUROMOD contains a module which performs this backward calculation. It is an "ad hoc" procedure which starts from a first guess for the gross income of a household. EUROMOD then calculates the corresponding disposable income. A comparison of this calculated disposable household income with the registered one is then used to update the first guess of household gross income in an iterative process until some criterion of convergence is met.

6 For a discussion of EUROMOD, see Sutherland (2001).

7 See Davies and Hoy (2002) for a formal treatment of the relation between the two available parameters in the context of revenue neutral reforms, and the application in Paulus and Peichl (2008). 
model. This means that the individual's choice set is not modelled in a (nearly) continuous way (e.g. the number of hours per week, subdivided into very small intervals), but as a limited number of discrete choices. In our application, the choice possibilities are limited to three: not working, working half-time and working fulltime.The version of the model estimated here is described in detail in Orsini (2006a, 2008) and summarized briefly in appendix 7.1.

To estimate labour supply, we pooled budget surveys for four different years: 1999, 2000, 2001 and 2002 amounting to a total number of 34,758 individual observations. It is obvious, however, that the labour supply was not modelled for individuals, like pensioners, who have left the labour market. Also other, smaller, groups are not modelled for several reasons. For the self-employed, for instance, both the concept of gross hourly wages and the variable "labour supply" as a number of contractually fixed hours per week poses problems. The labour supply model was therefore only estimated for salary and wage earners who may be potentially active on the labour market. In our application these are people between 18 and 65 who are not students or in any other way unavailable for the labour market (e.g. retired, disabled, etc.). At the household level, we also excluded mixed cases like individuals married to a retired person or a self-employed. In the end, we were able to explain and predict labour supply for four groups of individuals available for the labour market: single men, single women, men in couples and women in couples.

Indirect taxes are not (yet) modelled in EUROMOD. ${ }^{8}$ To add in this additional effect on revenues, we applied the indirect tax legislation - VAT-rates, excise taxes and advalorem taxes- of the year 2005 at the most disaggregated level of expenditures found in the budget survey of 2002 and calculated indirect tax rates on 16 aggregated commodity groups assuming fixed producer prices. ${ }^{9}$ These aggregate indirect tax rates were then used to determine indirect tax liabilities before and after the reform, taking into account changes in consumption, induced by eventual changes in disposable incomes.

We assumed that changes in disposable income due to the introduction of a flat tax are fully absorbed by changes in the consumption of non-durable consumption goods, i.e. expenditures on durable goods and saving are kept constant. ${ }^{10}$ The consumption changes were calculated by means of Engel curves that were estimated on the 2002 budget survey for 15 commodity groups (excluding durables) on the 2002 budget survey. The aggregate indirect tax rates were then used to determine indirect tax liabilities for the pre- and post reform expenditures.

8 Extending EUROMOD with indirect tax calculations is part of the EU-funded project called AIM-AP: "Accurate Income Measurement for the Assessment of Public Policies" (Contract no 028412); see http://www.iser.essex.ac.uk/msu/emod/aim-ap/project3.php.

9 For a thorough and detailed description of this procedure see Decoster et al. (2007).

10 In the analysis without behavioural effects the implicit assumption is that all changes in disposable income are (dis)saved. 
Note that, in this paper, we confine the role of expenditures and indirect taxes to their effect on government revenues. We do take indirect taxes into account to calculate cost recovery effects of the flat tax and to determine a revenue neutral rate. But we do not use the changes in consumption to go beyond disposable income as a crude proxy of welfare changes. ${ }^{11}$

\section{AVERAGE AND MARGINAL RATES IN THE BASIC SCENARIO}

\subsection{AVERAGE TAX RATES IN THE BELGIAN PERSONAL INCOME TAX}

For each family in the budget survey of 2002 we calculated by means of EUROMOD the average tax rate of the Belgian personal income tax. This average tax rate was obtained by dividing the personal income tax liability of the household by the sum of all taxable income in the household (after deducting work related expenses according to the fixed rate structure).

The average tax rate for all families in the budget survey is estimated at $17.5 \%$. This is higher than the average of $15.7 \%$ obtained on the fiscal data in Decoster and Van Camp (2005). ${ }^{12}$ Yet, the calculations based on the budget survey refer to the tax system after the personal income tax reform of 2001 which substantially lowered the average tax liability. One of the reasons for this is, of course, that in the budget survey we cannot take into account the myriad of real world tax reductions. Moreover, the household concept in the budget survey refers to a sociological family which is fundamentally different from the fiscal units in the fiscal data.

11 Remark that, for simplicity, we only consider real income and not relative price effects to derive the changes in consumption, and that we do not attempt at estimating a full demand system at this stage. For a more in-depth analysis of the effects of simultaneous changes in disposable income, leisure and consumption on the distribution of welfare, see Capéau, Decoster, De Swerdt and Orsini (2008).

12 The calculation of the tax liability on the fiscal data in Decoster and Van Camp (2005) was done by the research department of the the Belgian Ministry of Finance by means of the SIRe micro-simulation model, see Standaert and Valenduc (1996). 
TABLE 1: DISTRIBUTION OF THE AVERAGE TAX RATES IN CLASSES

\begin{tabular}{ccccc}
\hline \multicolumn{4}{c}{$\begin{array}{c}\text { \% of families with an average tax rate } \\
\text { in this class }\end{array}$} & \multicolumn{2}{c}{ Cumulative \% } \\
class & budget survey & fiscal data & budget survey & fiscal data \\
\hline 0 & 17.8 & 17.8 & 17.8 & 17.8 \\
0 to $5 \%$ & 8.3 & 12.0 & 26.1 & 29.8 \\
5 to $10 \%$ & 7.3 & 9.5 & 33.4 & 39.3 \\
10 to $15 \%$ & 9.1 & 8.5 & 42.5 & 47.8 \\
15 to $20 \%$ & 10.7 & 9.6 & 53.2 & 57.4 \\
20 to $25 \%$ & 13.1 & 12.8 & 66.3 & 70.2 \\
25 to $30 \%$ & 13.6 & 15.7 & 79.9 & 85.9 \\
30 to 35\% & 10.1 & 9.8 & 90.0 & 95.7 \\
35 to $40 \%$ & 6.7 & 3.4 & 96.7 & 99.1 \\
40 to $45 \%$ & 2.9 & 0.7 & 99.6 & 100.0 \\
45 to $50 \%$ & 0.4 & 0.2 & 100.0 & 100.0 \\
$>50 \%$ & 0.0 & 0.0 & 100.0 & \\
\hline
\end{tabular}

Table 1 compares the distribution of the average tax rate obtained from the budget survey with the distribution reported in Decoster and Van Camp (2005) on the fiscal data. The distribution of the average tax rates obtained from the budget survey in this reference scenario seems reasonable and reliable enough to be used as a benchmark of comparison for the flat tax simulations. Both datasets confirm the remarkable observation that over half the families face an average tax rate in the personal income tax of less than $20 \% .{ }^{13}$ Part of the explanation is the inclusion of the large group of families (almost 18\%) who pay no personal income tax at all.

Table 2 structures the same micro-information about average tax rates in different ways. We describe the average tax rate across deciles of equivalent disposable income, by most important source of income and by household type. Disposable income is the income after subtraction of the personal income tax liability. The equivalence scale is the square root of the number of persons in the household.

The comparison with calculations on the fiscal dataset again allows for an optimistic conclusion as regards the reliability of the reference scenario in the budget survey. The average tax rate rises through the deciles making the personal income tax system distinctly progressive (confirming Decoster and Van Camp, 2005). Only for the top deciles the average tax in the budget survey exceeds the one in the fiscal data. This is undoubtedly explained by the impossibility to take into account many tax reliefs in our

13 For a global picture of taxes on labour income, including social security contributions, see Decoster et al. (2008). 
budget survey calculations. In Decoster and Van Camp (2005) we showed that the switch from 'lump sum' to 'actual' (and proven) work related expenses mainly occurs in the highest decile. ${ }^{14}$

The importance of taking into account these proven work related expenses to measure how progressive the personal income tax system is, is also confirmed in the second part of Table 2. Only a negligible fraction of wage and salary earners declares actual expenses. The large majority opts for the legally provided fixed rate scheme instead. Consequently, our estimated average tax rate for the wage and salary earners in the budget survey $(22.3 \%)$ comes remarkably close to that obtained through the fiscal data $(22.2 \%)$. The same holds for families for whom the most important income is the replacement income. For those families whose main source of income is selfemployment income, however, the average tax rate $(30.1 \%)$ strongly deviates from that obtained in the fiscal data $(12.2 \%)$. The study of fiscal data indeed revealed that twothirds of fiscal families with mainly self-employment income declare actual incurred work related expenses rather than make use of the fixed deduction sheme provided for in the tax legislation.

The subdivision into family types based on the family's composition and age could be carried out in much greater detail in the budget survey than in the fiscal data. Age, for instance, was not available in the fiscal data. The results for this classification are therefore less comparable between the two datasets. Couples face a higher average tax rate than single people. Only the large families (three children or more) see their tax rate diminish substantially. Older single individuals have a much lower tax rate. It goes without saying that this univariate analysis does not correct for differences in taxable income between these socio-economic categories.

14 See Tables 7 and 8 in Decoster and Van Camp (2005). The average of the proven expenses amounts to $€ 3,910$ for all fiscal families, but in the highest decile, it is $€ 25,592$. The other deductions also increase with income, although to a lesser extent than proven work related expenses. 
TABLE 2: AVERAGE TAX RATES IN THE PERSONAL INCOME TAX FOR DECILES AND FOR SOCIOECONOMIC GROUPS (IN \%)

\begin{tabular}{|c|c|c|c|}
\hline \multicolumn{4}{|c|}{ average tax rate } \\
\hline & & budget survey & fiscal data \\
\hline all families & & 17.6 & 15.7 \\
\hline \multicolumn{4}{|c|}{ according to decile } \\
\hline 1 & & 1.1 & 0.4 \\
\hline 2 & & 3.3 & 3.1 \\
\hline 3 & & 8.2 & 5.5 \\
\hline 4 & & 11.6 & 11.2 \\
\hline 5 & & 15.9 & 16.5 \\
\hline 6 & & 20.3 & 21.2 \\
\hline 7 & & 23.9 & 24.2 \\
\hline 8 & & 27.4 & 26.5 \\
\hline 9 & & 31.3 & 28.6 \\
\hline 10 & & 37.3 & 28.1 \\
\hline \multicolumn{4}{|c|}{ according to income type } \\
\hline wages and salaries & & 22.3 & 22.2 \\
\hline replacement incomes & & 8.7 & 7.3 \\
\hline self-employment incomes & & 30.1 & 12.2 \\
\hline mixed incomes & & 10.8 & 17.8 \\
\hline \multicolumn{4}{|c|}{ according to family type } \\
\hline & & $\begin{array}{c}\text { in budget } \\
\text { survey }\end{array}$ & in fiscal data \\
\hline single, $<65$, no children & & 13.6 & \\
\hline single, $<65$, with children & Single & 12.2 & \\
\hline single, $>=65$ & & 7.0 & \\
\hline couple, $<65$, no children & & 22.5 & \\
\hline couple, $<65,1$ child & & 23.8 & \\
\hline couple, $<65,2$ children & & 24.8 & \\
\hline couple, $<65,3+$ children & & 17.8 & \\
\hline couple, $>=65$, no children & & 12.2 & \\
\hline \multirow[t]{3}{*}{ couple, $>=65$, with children } & & 14.4 & \\
\hline & single-income & & 10.7 \\
\hline & double-income & & 20.1 \\
\hline $\begin{array}{l}\text { Note: to calculate the average } \\
\text { of the population, sorte } \\
\text { classification is based o }\end{array}$ & $\begin{array}{l}\text { ax rate, see note } \mathrm{T} \\
\text { by equivalent dis } \\
\text { the age of the hea }\end{array}$ & $\begin{array}{l}\text { bole } 1 \text {. The decile } \\
\text { oosable income. } \\
\text { of the family. }\end{array}$ & $\begin{array}{l}\text { contain } 10 \% \\
\text { ne age }\end{array}$ \\
\hline
\end{tabular}

\subsection{DOES WORK PAY?}

The average tax rate does not tell the whole story. More important, especially with respect to labour supply, is the marginal tax rate. It is the key variable for labour supply at the "intensive" margin, i.e. for those who are already working. At least as important, however, is the participation tax rate. This shows the part of income taxed 
away by the joint working of the tax and benefit system when moving from inactivity to employment. Therefore, this participation tax rate is crucial in explaining the participation decision or the labour supply decision at what is called the "extensive margin". The micro-simulation model allows to calculate both marginal tax rates and participation tax rates at the individual level. Since we no longer compare with the fiscal data source and contrary to the results shown in Table 1 and 2, we also include the employee's contribution to social security here.

The results are shown in Table 3 in the form of distributions of the individuals over different tax rate brackets, both for the marginal tax rate (under the heading "hours"), and for the participation tax rate (under the heading "particip"). For calculating the marginal tax rate we had a working person working one extra hour. The marginal tax rate is then obtained as one minus the difference in available income divided by the additional earned income following the extra hour of work. The participation tax rate is derived from the difference in net income when working full-time as opposed to not working divided by earned income.

TABLE 3: DISTRIBUTION OF MARGINAL AND PARTICIPATION TAX RATES

\begin{tabular}{|c|c|c|c|c|c|c|c|c|}
\hline \multirow{3}{*}{$\begin{array}{l}\text { mar- } \\
\text { ginal } \\
\text { rate in } \\
\%\end{array}$} & \multicolumn{8}{|c|}{$\%$ of the subgroup belonging to a bracket of marginal rates } \\
\hline & \multicolumn{2}{|c|}{ single women } & \multicolumn{2}{|c|}{ single men } & \multicolumn{2}{|c|}{ women in couples } & \multicolumn{2}{|c|}{ men in couples } \\
\hline & hours & particip. & Hours & particip. & Hours & particip. & hours & particip. \\
\hline$(0 ; 10]$ & 0.0 & 0.8 & 0.0 & 0.0 & 0.0 & 0.0 & 0.0 & 0.0 \\
\hline$(10 ; 20]$ & 6.8 & 0.0 & 2.9 & 0.0 & 0.2 & 0.0 & 0.0 & 0.0 \\
\hline$(20 ; 30]$ & 0.8 & 0.6 & 0.0 & 0.0 & 0.0 & 0.0 & 0.0 & 0.0 \\
\hline$(30 ; 40]$ & 1.7 & 1.5 & 4.4 & 3.0 & 3.4 & 2.3 & 2.0 & 4.5 \\
\hline$(40 ; 50]$ & 23.2 & 7.8 & 21.2 & 5.4 & 32.9 & 14.9 & 25.3 & 8.3 \\
\hline$(50 ; 60]$ & 52.0 & 11.1 & 54.0 & 20.8 & 48.0 & 33.0 & 58.3 & 10.4 \\
\hline$(60 ; 70]$ & 1.1 & 33.0 & 1.8 & 41.6 & 1.4 & 37.2 & 1.0 & 10.9 \\
\hline$(70 ; 80]$ & 2.6 & 39.9 & 0.5 & 23.0 & 1.5 & 9.5 & 2.0 & 23.7 \\
\hline$(80 ; 90]$ & 4.6 & 5.3 & 3.8 & 6.2 & 2.4 & 2.4 & 1.5 & 30.3 \\
\hline$(90 ; \infty]$ & 7.3 & 0.0 & 11.6 & 0.0 & 9.1 & 0.8 & 10.0 & 11.9 \\
\hline Total & 100.0 & 100.0 & 100.0 & 100.0 & 100.0 & 100.0 & 100.0 & 100.0 \\
\hline
\end{tabular}

The difference from Table 1 is obvious: the majority of individuals in each of the four groups face marginal and participation tax rates of more than $50 \%$. Of course, this difference with Table 1 is partly explained by the fact that social security contributions are taken into account. But still, the much smaller spread is noticeable. Take, for instance, the marginal tax rate at the intensive margin for singles. More than half of these persons face tax rates between $50 \%$ and $60 \%$. For men in couples, this is as high as $58 \%$. The comparison between the marginal tax rates at the intensive and extensive margin shows that the latter are even higher. Slightly less than $40 \%$ of non active women face participation tax rates between $70 \%$ and $80 \%$. In the category of non-active 
single men we also find almost two-thirds (of, indeed, a smaller group) with tax rates varying between $60 \%$ and $80 \%$.

\section{A REVENUE-NEUtral FLAT tAX Without BEHAVIOURAL EFFECTS}

Before considering the feedback effects of the introduction of a flat tax, we examine the flat tax scenarios without behavioural effects. According to the National Institute for Statistics, the personal income tax revenue amounted to $€ 35,298$ billion in 2005 . As can be seen in the first column of Table 4, we slightly overestimate the baseline tax revenue in the budget survey ( $€ 38,902$ billion). All revenue-neutral flat taxes are defined with respect to this point of reference.

TABLE 4: REVENUE IN THE BASELINE SCENARIO AND FOR TWO FLAT TAXES (IN MILLION €)

\begin{tabular}{lccc}
\hline Description & baseline & $\begin{array}{c}\text { proportional } \\
\text { taxes, no } \\
\text { exemptions }\end{array}$ & $\begin{array}{c}\text { flat tax with } \\
\text { exemptions }\end{array}$ \\
\hline flat rate (in \%) & - & 26.0 & 38.50 \\
\hline personal income tax revenue & 38,904 & 38,640 & 38,897 \\
employee social contribution revenue & 14,671 & 14,671 & 14,671 \\
employer social contribution revenue & 21,755 & 21,755 & 21,755 \\
expenses guaranteed minimum income benefit & 2,376 & 3,299 & 2,838 \\
expenses unemployment benefit & 6,650 & 6,650 & 6,650 \\
indirect tax revenue & 12,069 & 12,069 & 12,069 \\
\hline Net Budget & 78,373 & 77,186 & 77,904 \\
\hline
\end{tabular}

We calculated the effects of two flat taxes: a strictly proportional tax and a constant marginal rate above an exemption level. The exemptions are those from the current system and are applied as a tax reduction, calculated as the tax amount due on this exempted income (without refunding however). The results are shown in Tables 4 (for the revenues) and 5 (for the distributional effects).

The first line of Table 4 displays the flat tax rate needed to reach revenue neutrality with respect to the baseline situation in the first column. For the strictly proportional tax in the second column, we defined revenue neutrality with respect to the personal income tax revenues only. In that case, the tax must be set at $26 \%$. As expected, the distributional effects of this proportional tax, as shown in Table 5, are disastrous for the lower half of the income distribution. Compared to an average gain of $1.3 \%$ in disposable income for the population as a whole, there is a $10 \%$ loss for the poorest $40 \%$ of the population and a gain of almost $21 \%$ for the richest $10 \% .{ }^{15}$ Since the proportional tax removes all progression from the personal income tax, this effect once more reveals the fact that the current personal income tax system is still genuinely

15 In the lower half of the distribution, replacement income (including pensions) represents a considerable share of disposable income. 
progressive, and hence redistributive. The results in the first column of Table 5 simply restate the increasing average tax rates in the baseline of Table 2.

TABLE 5: DISTRIBUTIONAL EFFECTS OF REVENUE-NEUTRAL FLAT TAXES

(\% CHANGE IN EQUIVALISED DISPOSABLE INCOME)

\begin{tabular}{|c|c|c|}
\hline Description & $\begin{array}{c}\text { proportional tax, } \\
\text { no exemptions }\end{array}$ & $\begin{array}{c}\text { flat taxes with } \\
\text { exemptions }\end{array}$ \\
\hline flat rate (in \%) & 26.0 & 38.5 \\
\hline$\%$ change available income of all families & 1.3 & 0.5 \\
\hline \multicolumn{3}{|c|}{ by decile } \\
\hline 1 & -12.5 & -1.8 \\
\hline 2 & -12.7 & -5.0 \\
\hline 3 & -13.6 & -8.1 \\
\hline 4 & -10.9 & -5.4 \\
\hline 5 & -7.8 & -3.9 \\
\hline 6 & -4.4 & -2.4 \\
\hline 7 & -0.7 & -0.2 \\
\hline 8 & 3.0 & 1.0 \\
\hline 9 & 8.9 & 3.7 \\
\hline 10 & 20.6 & 9.4 \\
\hline \multicolumn{3}{|c|}{ by income type } \\
\hline wages and salaries & 2.1 & 1.5 \\
\hline replacement incomes & -10.1 & -6.5 \\
\hline self-employment incomes & 12.9 & 6.3 \\
\hline mixed incomes & 29.5 & 13.8 \\
\hline \multicolumn{3}{|c|}{ by family type } \\
\hline single, $<65$, no children & -3.3 & 3.2 \\
\hline single, $<65$, with children & -5.1 & 3.5 \\
\hline single, $>=65$ & -12.5 & -1.6 \\
\hline couple, $<65$, no children & 5.2 & 0.1 \\
\hline couple, $<65,1$ child & 4.3 & 1.3 \\
\hline couple, $<65,2$ children & 5.8 & 2.9 \\
\hline couple, $<65,>=3$ children & 0.1 & 1.4 \\
\hline couple, $>=65$, no children & -7.6 & -9.8 \\
\hline couple, $>=65$, with children & -7.0 & -7.6 \\
\hline
\end{tabular}

This drastic loss of disposable income in the bottom half of the distribution is also reflected in the expenses for the guaranteed minimum income benefit. These increase from $€ 2,376$ million to $€ 3,299$ million under this proportional tax scenario. ${ }^{16}$ Hence, even in a model with no behavioural effects on the labour supply side, a first likely feedback effect has been identified.

16 The model does not model any behaviour for the take-up of this minimum income guarantee. It is attributed to everyone who qualifies for it, based on a comparison of the incomes with the subsistence level for the category of families to which the individual belongs. It is thus an upper limit for these expenses. 
Politically, the scenario of a proportional tax seems highly unlikely. In the second flat tax we therefore reintroduce the exemptions of the baseline system. Furthermore, the second flat tax is made revenue-neutral with respect to the net budgetary effect exclusive of guaranteed minimum income benefit expenses, that is the sum of personal income taxes, indirect taxes, employee social security contributions, and employer social security contributions, less unemployment benefits. These results, displayed in the third column of Table 4 again confirm the results from Decoster and Van Camp (2005):

- The introduction of basic exemptions causes the revenue-neutral flat tax rate to rise substantially: to make it more or less revenue neutral we now need a rate of $38.5 \%$. As can be derived from the right column of Table 4, the expenses for the guaranteed minimum income benefit again drop to $€ 2,838$ million but still remain $€ 462$ million above the expenses in the basic scenario.

- A flat tax with exemptions avoids the social carnage of the first column in Table 5, but also the gains of this reform remain strongly regressive. The average gain of $0.5 \%$ hides a large variation. Only the upper three deciles benefit with respect to disposable income. All other deciles lose. The disposable income of the top decile increases by $9.4 \%$, but the loss in the deciles 2,3 and 4 still amounts to $5 \%$ and more.

- Introduction of the basic exemption levels does not compensate the tax reliefs for replacement incomes (which are still removed). Since households with replacement incomes are mainly found in the lowest three deciles, this also explains the pattern of the losses according to income.

- On average, the flat tax reform redistributes from households with replacement incomes to families with income from self-employment activity. On average, the wage and salary earners experience a small gain.

- The younger gain, the older lose.

The important question now is whether this high price in terms of distribution can be justified by a substantial gain in efficiency. This is the subject of the next section, where we will investigate the labour supply effect of the tax reform.

\section{EFFECTS OF A FLAT TAX ON LABOUR SUPPLY}

In public policy debates, the "efficiency" argument is often reduced to "costrecovery" effects. In short, advocates of the flat tax consider the above increase of the flat tax rate to $38.5 \%$ unrealistically high since the flat tax might induce more people to enter the labour market and/or to increase their labour supply. This in turn will increase the taxable base and hence allow a lower revenue neutral flat tax rate. In this section we first discuss this cost-recovery effect. The next subsection focuses on the reactions with regard to labour market participation and/or hours of work 
(section 5.2). In section 5.3 we verify whether accounting for labour supply reactions modifies the above-mentioned distributional effects of the introduction of a flat tax.

\subsection{HOW STRONG IS THE COST-RECOVERY EFFECT?}

We first keep the flat tax rate at the above-mentioned level of $38.5 \%$ and compare the budgetary effects with and without labour supply reactions. Probably, this most closely resembles what policy makers refer to as the "cost-recovery effect". ${ }^{17}$

TABLE 6: BUDGET CHANGE THROUGH INTRODUCTION OF LABOUR SUPPLY REACTIONS (IN MILLION €)

\begin{tabular}{lccc}
\hline Description & $\begin{array}{c}\mathbf{( 1 )} \\
\text { flat tax } \mathbf{3 8 . 5 \%} \\
\text { fixed labour } \\
\text { supply } \\
\text { revenue in } \\
\text { million } €\end{array}$ & $\begin{array}{c}\mathbf{( 2 )} \\
\text { flat tax } \mathbf{3 8 . 5 \%} \\
\text { endogenous labour } \\
\text { supply } \\
\text { change in million } € \\
\text { compared to (1) }\end{array}$ & $\begin{array}{c}\mathbf{( 3 )} \\
\text { flat tax 37\% } \\
\text { endogenous } \\
\text { labour supply } \\
\text { change in } \\
\text { million } € \\
\text { compared to (2) }\end{array}$ \\
\hline personal income tax & 38,743 & 369 & -1473 \\
employee social contributions & 14,735 & 198 & 21 \\
employer social contributions & 20,685 & 441 & 45 \\
guaranteed minimum income benefit & 3,032 & 10 & -61 \\
unemployment benefit & 6,304 & -98 & -9 \\
indirect tax revenue & 12,325 & 109 & 189 \\
net effect on the budget & 77,152 & 1,205 & $-1,148$ \\
\hline
\end{tabular}

The first column in Table 6 replicates the baseline -the revenue neutral flat tax of $38.5 \%$ - but starting from the calibrated labour supply model (see appendix 7.1 for more details). ${ }^{18}$ The second column shows the change in revenues and government spending if we introduce labour supply effects. There are indeed substantial feedback effects that are not accounted for in a strict impact analysis. The increase of both personal income tax ( $€ 369$ million or $0.95 \%)$ and social security contributions ( $€ 639$ million or $1.8 \%$ ) on the one hand and the decrease in unemployment benefits (by $€ 98$ million or 1.6\%) on the other hand, indicate that, on average, there is increased activity on the labour market. We also take up the effect of increased disposable income on indirect tax revenues ( $€ 109$ million or $0.88 \%$ ). Taken together, there is a

17 In the public debate one refers to the "cost recovery" of a tax reduction as the percentage of the initial forgone tax revenue which is earned back through the interplay of behavioural and general equilibrium effects. Of course, if we first determine the tax rate as revenue neutral, the forgone revenue equals zero, and the percentage cost recovery measure makes no sense. In appendix 7.2 we therefore also give some numerical values of the cost recovery for non revenue neutral reforms.

18 With "calibrated" we refer to the fact that the baseline is calculated using the probabilities, and hence the stochastic nature, of the labour supply model as described in appendix 7.1. We opted to present results this way for consistency. 
budget surplus of $€ 1,205$ million because of changes in behaviour compared to the situation in which behavioural changes are not taken into account.

Another way to look at this cost recovery effect, is to calculate how much the previously revenue neutral flat tax rate of $38.5 \%$ can be lowered if additional revenues are taken into account. In terms of Table 6, the extra revenue of $€ 1,205$ million (last line of the second column) can be used to reduce the $38.5 \%$ rate and still remain budgetary neutral. This is shown in the rightmost column of Table 6. It shows the difference in revenues and government spending by moving from a $38.5 \%$ rate to a $37 \%$ rate, again taking into account labour supply effects. Expressed in this way, the cost recovery effect is much less spectacular. Lowering the rate with 1.5 percentage point immediately eats away 1,473 million of the budget surplus of 1,205 million. The reason is of course that the reduction with 1.5 percentage point bears on the entire taxable base of personal income taxes and not only on the additional tax base created in the previous step. Although part of the loss is recovered through more favourable changes in other revenues and spending, this once more illustrates that proposals endorsing a flat tax rate of $25 \%$ based on cost-recovery arguments, can only be labeled populistic.

Presumably, the labour supply reaction will not be equally distributed across the population. In the next section we examine in detail the labour supply reactions. The results in the following two sections are calculated using the new revenue-neutral flat tax rate of $37 \%$.

\subsection{WHO REACTS TO THE STIMULUS OF THE FLAT TAX?}

As described in appendix 7.1, labour supply is modelled separately for single men, single women, and men and women in couples. In addition, aside from the net wages, other explanatory variables like age, education and the number of children are used to account for the observed labour supply. This allows for a disaggregated picture of labour supply reactions.

In Table 7, the mechanism of the labour supply model is illustrated by means of elasticities for different groups. The column with the heading "all" contains two elasticities for each modelled subgroup. The "participation elasticity" reflects the change in the degree of participation (in percentage points) following a $1 \%$ increase in the gross hourly wages (and an unchanged tax system). This concept summarises the extent to which an increase in the gross hourly wages will encourage the non-active to enter the labour market or, although less probable, will motivate the active to leave the labour market. The "hours elasticity" adds the reaction of individuals who are already active to the previous "extensive margin". Those currently working may choose to work more or less. The hours elasticity shown in Table 7 shows the percentage change of the total number of hours worked by each subgroup following the same $1 \%$ increase in the gross hourly wages. Note that the hours elasticity represented here is the cumulative effect of changes at the intensive and at the extensive margin. It contains 
both the participation elasticity (in which the change in labour market participation is expressed in number of hours) and the reaction of those who are already working.

The elasticities are in line with estimates reported in the literature for other countries. ${ }^{19}$ The largest labour supply reaction is found among women. An increase in the gross hourly wages by $1 \%$ causes the labour supply to increase by $0.27 \%$ for single women and even $0.30 \%$ for women in couples. For men, the elasticity is $0.29 \%$ when single but only $0.08 \%$ when living with a partner. The labour supply reaction is mainly driven by the change in labour market participation and to a much lesser extent by a change in the labour supply of those who are already working.

TABLE 7: LABOUR SUPPLY ELASTICITIES FOR DIFFERENT GROUPS

\begin{tabular}{|c|c|c|c|c|c|}
\hline & \multirow[t]{2}{*}{ all } & \multicolumn{4}{|c|}{ Quartile in distrib. gross incomes } \\
\hline & & $\begin{array}{c}\text { Q1 } \\
\text { (lowest } \\
25 \% \text { ) }\end{array}$ & Q2 & Q3 & $\begin{array}{c}\text { Q4 } \\
\text { (highest } \\
25 \% \text { ) }\end{array}$ \\
\hline & \multicolumn{5}{|c|}{ Single men } \\
\hline participation rate $(\%)$ & 75.54 & 12.23 & 94.82 & 99.06 & 96.27 \\
\hline participation elasticity & 0.27 & 2.58 & 0.09 & 0.02 & 0.00 \\
\hline \multirow[t]{2}{*}{ hours elasticity } & 0.29 & 3.56 & 0.08 & 0.03 & 0.00 \\
\hline & \multicolumn{5}{|c|}{ Single women } \\
\hline participation rate (\%) & 74.05 & 11.97 & 87.48 & 97.00 & 100.00 \\
\hline participation elasticity & 0.30 & 2.66 & 0.22 & 0.00 & 0.00 \\
\hline \multirow[t]{2}{*}{ hours elasticity } & 0.27 & 4.53 & 0.23 & -0.02 & -0.18 \\
\hline & \multicolumn{5}{|c|}{ Men in couples } \\
\hline participation rate $(\%)$ & 93.82 & 84.59 & 96.94 & 95.58 & 98.16 \\
\hline participation elasticity & 0.07 & 0.26 & 0.02 & 0.03 & 0.00 \\
\hline \multirow[t]{2}{*}{ hours elasticity } & 0.08 & 0.29 & 0.03 & 0.04 & 0.01 \\
\hline & \multicolumn{5}{|c|}{ Women in couples } \\
\hline participation rate $(\%)$ & 63.63 & 16.44 & 69.77 & 83.16 & 85.24 \\
\hline participation elasticity & 0.27 & 1.74 & 0.25 & 0.09 & 0.08 \\
\hline hours elasticity & 0.30 & 2.13 & 0.30 & 0.14 & 0.10 \\
\hline
\end{tabular}

In addition to the distinction between the four subgroups in the horizontal panels of Table 7, we also show the reactions for different groups in the distribution of gross incomes. The underlying population of modelled individuals is divided into four quartiles from low to high gross labour income. The difference in labour supply reaction is obvious. The positive reaction comes mainly from the lowest quartile. In

19 See e.g. the recent overview in Orsini (2006b, 2008). 
contrast, for women with high incomes we observe a "backward bending" labour supply curve. ${ }^{20}$

The introduction of a flat tax modifies the net gain of employment and hence the choice whether or not to supply labour and, if supplied, how much. Table 8 shows the employment effects of introducing a flat tax of $37 \%$. We again distinguish between the effects on participation and the (combined) effect on the number of hours by including the reaction of those who are already working.

TABLE 8: EFFECTS OF THE FLAT TAX ON LABOUR SUPPLY

\begin{tabular}{lcccc}
\hline & basic scenario & flat tax & $\begin{array}{c}\text { difference in } \\
\text { units }\end{array}$ & difference in \% \\
\hline Employment & 316,439 & 318,751 & 2,312 & 0.7 \\
single women & 255,112 & 259,274 & 4,162 & 1.6 \\
single men & 815,170 & 853,723 & 38,553 & 4.7 \\
women in couples & $1,202,244$ & $1,204,567$ & 2,323 & 0.2 \\
men in couples & $2,588,965$ & $2,636,315$ & 47,350 & 1.8 \\
Total employment & & & & \\
& & & & \\
Hours & $10,902,404$ & $11,028,722$ & 126,318 & 1.2 \\
single women & $9,695,688$ & $9,931,213$ & 235,525 & 2.4 \\
single men & $25,054,267$ & $26,399,587$ & $1,345,320$ & 5.4 \\
Women in couples & $46,865,730$ & $47,051,780$ & 186,050 & 0.4 \\
men in couples & $92,518,089$ & $94,411,302$ & $1,893,213$ & 2.0 \\
Total number of hours & $2,312,952$ & $2,360,283$ & 47,330 & 2.0 \\
Total FTE & & & & \\
\hline
\end{tabular}

In the baseline situation the model produces an employment of 2,588,965 working people, or 2,312,952 full-time equivalents. According to the labour supply model, introducing a flat tax of $37 \%$ causes a net increase of 47,350 units or $1.8 \%$. By far the largest reaction (38,553 units or a $4.7 \%$ increase in employment) is found among women in couples. Needless to emphasise again that this is a reaction of labour supply, without taking into account the demand side of the labour market. In other words, this (net) effect identifies those who did not find it profitable to offer labour before the introduction of a flat tax, but do so after the introduction. The demand side of the labour market is not modelled and it is therefore not possible to predict whether this increased labour supply will meet a matching labour demand. In the lower part of Table 8 , we add the effect of people who were already working. This causes the overall increase in the labour supply to rise further from $1.8 \%$ to $2.0 \%$.

20 A more thorough statistical analysis of these labour supply effects could, in fact, reveal that not all of these effects are also statistically significant. The confidence intervals for the estimates of this labour supply model have not yet been calculated. 


\subsection{DO LABOUR SUPPLY REACTIONS MODIFY THE ADVERSE DISTRIBUTIONAL EFFECTS OF A FLAT TAX?}

The advantages of a behavioural micro-simulation model lie in the possibility to account for the heterogeneity of individuals and families in the population. Table 7 clearly shows that the labour supply reaction varies among the different groups and according to the gross hourly wage. In this subsection we therefore investigate whether the labour supply reaction could amend the strongly regressive effects of a flat tax.

Table 9 describes the characteristics of the modelled subpopulation in terms of their labour supply reaction. Each row of the table represents a subgroup according to the size of the labour supply reaction, and each column describes a characteristic of the individuals in this specific subgroup. This allows portraying the different groups of people who react to the modified incentives. The fifth row, for instance, contains the group of individuals for whom the labour supply slightly decreases with the introduction of the flat tax (a decrease of between 2.5 and 0.1 hours per week). ${ }^{21}$ This group makes up $10.3 \%$ of the modelled population and comprises $95.9 \%$ of individuals who are in couples. A comparison with the last line in the table shows that individuals from couples are overrepresented in this group.

Table 9 shows that the majority of individuals hardly reacts if at all to the change in net income out of work: $50.7 \%$ of the subpopulation shows a change in the weekly labour supply between -0.1 and +0.1 hours (middle row in the table). Individuals who do react positively to the introduction of a flat tax are mainly women (since men are underrepresented in these groups) who live with a partner (because couples are overrepresented). Their gross income is slightly higher than average. Surprisingly, gross hourly wage does not vary monotonically across the range of labour supply reactions. We find high gross wages among those who have a strong negative reaction and among those who have a strong positive reaction. The small group that has the strongest negative reactions (first line) comprises men in couples with a high gross wage. Yet, the next, also small, group with a strong negative reaction consists of women with children but with a low gross wage.

It cannot be precluded that this varied pattern of the labour supply reaction also affects the conclusions on the distributional impact of introducing a flat tax. Table 10 compares the distributional effects of a revenue-neutral flat tax reform both without and with labour supply reactions. Note that in doing so, we switch again from the subpopulation of modelled individuals to the full population (including e.g. the pensioners) and to a representation at the household level. The table shows the percentage change in disposable income.

21 As the labour supply model is a discrete choice model, each possible option receives a certain probability. The individual prediction of labour supply thus relates to an expected value based on these probabilities (and the changes thereof). Therefore, at the individual level, we sometimes find small reactions. 
TABLE 9: CHARACTERISTICS OF THE FAMILIES ACCORDING TO THEIR LABOUR SUPPLY REACTION

\begin{tabular}{|c|c|c|c|c|c|c|c|c|}
\hline $\begin{array}{l}\text { labour } \\
\text { supply } \\
\text { reaction } \\
\text { in hours } \\
\text { per week }\end{array}$ & $\begin{array}{l}\text { population( } \\
\text { units) }\end{array}$ & $\begin{array}{l}\text { share in } \\
\text { population } \\
\text { in } \%\end{array}$ & $\begin{array}{c}\text { share in } \\
\text { couples } \\
\text { in } \%\end{array}$ & $\begin{array}{l}\text { share } \\
\text { men in } \\
\%\end{array}$ & age & $\begin{array}{l}\text { number } \\
\text { of } \\
\text { children }\end{array}$ & $\begin{array}{l}\text { gross } \\
\text { hourly } \\
\text { wage in } \\
€\end{array}$ & $\begin{array}{c}\text { household } \\
\text { disposable } \\
\text { income in } € \\
\text { per month }\end{array}$ \\
\hline$(-\infty ;-10]$ & 814 & 0.0 & 100.0 & 100.0 & 43.0 & 3.0 & 24.9 & 8002 \\
\hline$(-10 ;-7.5]$ & 853 & 0.0 & 49.1 & 0.0 & 32.0 & 0.0 & 7.6 & 4801 \\
\hline$(-7.5 ;-5]$ & 1834 & 0.1 & 100.0 & 76.5 & 58.5 & 0.5 & 14.6 & 3782 \\
\hline$(-5 ;-2.5]$ & 7084 & 0.3 & 100.0 & 43.5 & 48.7 & 0.1 & 14.7 & 3558 \\
\hline$(-2.5 ;-0.1]$ & 272814 & 10.3 & 95.9 & 65.4 & 41.6 & 1.2 & 12.2 & 2482 \\
\hline$(-0.1 ; 0.1]$ & 1336466 & 50.7 & 76.2 & 58.7 & 40.6 & 1.2 & 12.8 & 2490 \\
\hline$(0.1 ; 2.5]$ & 792097 & 30.0 & 73.6 & 33.7 & 41.4 & 1.2 & 14.3 & 2764 \\
\hline$(2.5 ; 5]$ & 132473 & 5.0 & 81.6 & 21.0 & 45.3 & 1.1 & 13.7 & 2329 \\
\hline$(5 ; 7.5]$ & 69406 & 2.6 & 85.2 & 23.3 & 47.2 & 1.0 & 14.8 & 2315 \\
\hline$(7.5 ; 10]$ & 15452 & 0.6 & 88.0 & 17.8 & 44.5 & 0.7 & 14.2 & 2024 \\
\hline$(10, \infty]$ & 6826 & 0.3 & 100.0 & 44.8 & 50.8 & 0.0 & 14.3 & 1916 \\
\hline all & 2636119 & 100.0 & 78.3 & 48.7 & 41.4 & 1.2 & 13.3 & 2561 \\
\hline
\end{tabular}

Here, too, the conclusion is qualified. The average gain increases (from $1.3 \%$ to $2.5 \%$ ) since the revenue neutral rate goes down from $38.5 \%$ to $37 \%$. The labour supply effects mitigate the regressive nature of the gains from the flat tax reform in disposable income terms. Still, the broad pattern of adverse distributional consequences remains: the lower half of the income distribution, and especially replacement incomes and older people, lose. The gain of disposable income of the top three deciles is even reinforced.

Note that this analysis only takes into account the change in disposable income. It is self-evident that this is not a comprehensive welfare analysis, neither at the individual or family level nor from a social point of view. Indeed, we neither account for the loss of leisure in the individual welfare metric, nor for eventual positive externalities linked with increased labour market participation. 
TABLE 10: DISTRIBUTIONAL EFFECTS OF FLAT TAXES WITH LABOUR SUPPLY (\% CHANGE OF DISPOSABLE INCOME)

\begin{tabular}{|c|c|c|}
\hline Description & $\begin{array}{l}\text { without } \\
\text { behavioural } \\
\text { reactions }\end{array}$ & $\begin{array}{c}\text { with } \\
\text { behavioural } \\
\text { reactions }\end{array}$ \\
\hline flat rate (in \%) & 39 & 38 \\
\hline all families & 1.3 & 2.5 \\
\hline \multicolumn{3}{|c|}{ per decile } \\
\hline 1 & -1.1 & -0.8 \\
\hline 2 & -3.9 & -3.6 \\
\hline 3 & -6.7 & -6.0 \\
\hline 4 & -4.4 & -3.6 \\
\hline 5 & -3.1 & -2.1 \\
\hline 6 & -1.3 & -0.2 \\
\hline 7 & 0.5 & 1.7 \\
\hline 8 & 1.7 & 3.1 \\
\hline 9 & 4.5 & 6.1 \\
\hline 10 & 9.7 & 11.7 \\
\hline \multicolumn{3}{|c|}{ per type of income } \\
\hline wages and salaries & 2.7 & 3.9 \\
\hline replacement income & -6.1 & -5.2 \\
\hline self-employment income & 6.3 & 8.0 \\
\hline mixed income & 11.8 & 14.0 \\
\hline \multicolumn{3}{|c|}{ per family type } \\
\hline single, $<65$, no children & 3.6 & 4.7 \\
\hline single, $<65$, with children & 3.6 & 4.4 \\
\hline single, $>=65$ & -1.5 & -0.7 \\
\hline couple, $<65$, no children & 1.1 & 2.6 \\
\hline couple $,<65,1$ child & 2.1 & 3.5 \\
\hline couple, $<65,2$ children & 3.6 & 5.0 \\
\hline couple, $<65,>=3$ children & 2.6 & 3.6 \\
\hline couple, $>=65$, no children & -9.4 & -8.1 \\
\hline couple, $>=65$, with children & -6.9 & -5.8 \\
\hline
\end{tabular}




\section{Conclusion}

As a substitute for the present personal income tax, the flat tax is a textbook example of a trade-off between equity and efficiency. The lower marginal rate of a flat tax might improve incentives (at least in some part of the wage or gross income distribution). However, the constant marginal rate, even above an exempted minimum, leads to a reduction in progressivity and hence redistributive power of the personal income tax.

Previous empirical research in Decoster and Van Camp (2005) or Valenduc (2006) on Belgian fiscal data already revealed that a realistic (i.e. budget-neutral) flat tax produces considerable adverse distributional effects. The analysis in this paper once more confirms this result. Advocates of the flat tax, however, rightly pointed out that these studies did not take into account the potential cost-recovery effect. In this paper we used a micro-econometric labour supply model and a micro-simulation model to counter this objection, without having to abandon the wealth of heterogeneity in the previous analysis.

The results are clear: compared to a pure impact analysis in which the behavioural effects were neglected, we estimate the cost-recovery effect of a flat tax to be about $€ 1,205$ million. This follows from an increase in the labour supply by about 47,000 fulltime equivalents, in turn leading to an increase in revenue from personal income tax and social contribution revenues of $€ 369$ million and $€ 639$ million respectively, and to a decrease in unemployment benefits of $€ 98$ million. There is also a slight increase in the expenses for guaranteed minimum income benefits of $€ 10$ million and an increase in indirect tax revenue of $€ 109$ million.

This appears to be a significant cost-recovery effect but is still rather limited. This is most obvious when we compare the revenue-neutral flat tax rate without and with cost-recovery effects. The cost-recovery effect allows the flat tax rate to diminish from $38.5 \%$ to $37 \%$. This confirms our previous results that advocating flat tax rates in the order of $20 \%$ or $25 \%$ is simply populistic. If not, advocates of such non revenue neutral rates should muster the intellectual honesty to make clear that not the flat tax itself but a strong reduction of government spending is the subject of political deliberation.

We emphasize that our estimates probably represent an upper bound of the costrecovery effect. After all, we could only model labour supply, not demand or other general equilibrium effects. This means that we assume that everybody who offers extra labour effectively finds a matching demand for it. It goes without saying that this is too optimistic an assumption. Additionally, it cannot be ruled out that the estimates of the labour supply model itself are also affected by omitting the limitations on the demand side of the labour market. ${ }^{22}$ Also other important reactions remain

22 See Bargain et al. (2005) for an empirical confirmation of this hypothesis. 
unmodelled in this paper: a change in evasion or avoidance behaviour, for instance, or shifting taxable income to other forms of declaration.

The labour supply reactions do not change the very regressive nature of the flat tax reform. Especially without further refinements (like tax reductions for replacement incomes in the present system), a simplistic introduction of a flat tax seems to be politically unrealistic. The large gain in disposable income for the three highest deciles and the losses for the lower half of the income distribution seem a high price, for a limited positive incentive effect on the efficiency side of the economic coin.

A topic that does deserve continued attention however is the high marginal tax burden on labour. For most individuals, the marginal tax rates calculated in this paper are over $50 \%$, and for the participation taxes even between $60 \%$ and $80 \%$. Of course, the treatment of social contributions as "taxes" is a point of view which is open to debate. Anyhow, we do not believe that a flat tax, at least in the form proposed in the Belgian public policy debate, provides a feasible, let alone "the best", solution to this high tax burden on labour. Returning the flat tax discussion to the domain where it was initially introduced, in particular as a progressive consumption tax, however, may be much more promising.

\section{APPENDIX}

\subsection{THE LABOUR SUPPLY MODEL}

Traditional approaches, based on the estimation of continuous labor supply functions, have proven computationally cumbersome even in the simplest case, let alone in the more complex cases in which multiple welfare program participation, the social stigma of benefit take up and the fixed cost of labor supply are considered. The modelisation of labour supply behaviour has been greatly simplified by the discrete approach proposed by van Soest (1995). The latter, in particular, builds on the observation that institutional constraints result in a limited set of working time alternatives (inactivity, some part-time categories, full-time and over-time), significantly reducing the computational burden of the estimation.

Suppose that each partner in a couple may supply a finite number of working hours; each combination $j$ of working hours of the partners $j=0, \ldots, J$ corresponds to a given level of gross labour market income. After adding non labour income and applying the microsimulation model, we derive the set of disposable incomes $C_{i j}$ (we suppose here that choice $j=0$ corresponds to non-participation) and each discrete bundle of leisure and income provides a different level of utility. ${ }^{23}$

23 The term leisure should be interpreted as non-labour market time. 
We assumed that each partner may work 0,20 , or 40 hours, corresponding to non participation, part-time, and full-time employment. It implies that a couple can choose among 9 alternative working hour combinations. Each alternative is characterized by a triplet of disposable income, leisure of the female partner and leisure of the male partner.

The model is based on random utility: the utility household $i$ derives from making choice $j, V_{i j}$, corresponds to the sum of the deterministic part of utility $U_{i j}$, which is assumed to depend on a function of spouses' leisure $L f_{j}, L m_{j}$, disposable income $C_{i j}$ and household characteristics $Z_{i}$, and of a random term $\varepsilon_{i j}$, unknown to the econometrician, but possibly known by the agents: 24

$$
V_{i j}=U\left(L f_{i j}, L m_{i j}, C_{i j}, Z_{i}\right)+\varepsilon_{i j} .
$$

If the error term $\varepsilon_{i j}$ is assumed to be identically and independently distributed across alternatives and households according to a extreme value distribution, McFadden (1974) proves that the probability that alternative $k$ is chosen by household $i$ is given by:

$$
P_{i k}=\operatorname{Pr}\left(V_{i k} \geq V_{i j}, \forall j=0, \ldots, J\right)=\frac{\exp U\left(L f_{i k}, L m_{i k}, C_{i k}, Z_{i}\right)}{\sum_{j=0}^{J} \exp U\left(L f_{i j}, L m_{i j}, C_{i j}, Z_{i}\right)} .
$$

Conditional on a functional specification of the utility function, it is possible to estimate the preference parameters. In the following, we assume a quadratic specification of the utility function, as in Blundell et al. (2000):

$$
\begin{aligned}
U_{i j}= & \alpha_{c} C_{i j}+\alpha_{c c} C_{i j}^{2}+\alpha_{l f} L f_{i j}+\alpha_{l l f} L f_{i j}^{2}+\alpha_{l m} L m_{i j}+\alpha_{l l m} L m_{i j}^{2} \\
& +\alpha_{c l f} C_{i j} L f_{i j}+\alpha_{c l m} C_{i j} L m_{i j}+\alpha_{l m l f} L f_{i j} L m_{i j} .
\end{aligned}
$$

We allow preferences to vary across households through taste-shifters on the income and leisure coefficients:

$$
\begin{aligned}
& \alpha_{c}=\alpha_{c 0}+\alpha_{c 1} X_{c} \\
& \alpha_{l f}=\alpha_{l f 0}+\alpha_{l f 1} X_{l} f \\
& \alpha_{l m}=\alpha_{l m 0}+\alpha_{l m 1} X_{l} m,
\end{aligned}
$$

where $X_{c}, X_{l} f$, and $X_{l} m$ are vectors of observed heterogeneity (age, number and age of children).

24 Leisure, $L f_{j}$ and $L m_{j}$ are respectively defined as $80-H f_{j}$ and $80-H m_{j}$, where $H f_{j}$ and $\mathrm{Hm}_{j}$ represent hours worked by the female and male respectively. 


\subsubsection{Wage estimation}

In order to simulate the budget constraint of each household, we need gross labour income at different hours worked. The standard hypothesis is that the hourly wage is fixed, so that gross labour income corresponds to gross hourly wage times the amount of hours worked. The gross hourly wage is derived for all employees by dividing the gross monthly wage by the number of hours worked per month. We then still have to impute a wage rate for inactive and unemployed workers. For this purpose the hourly wage was first estimated (separately for males and females) on the whole sample of individuals in working age (either employed, unemployed or inactive) using a Heckman correction model (Heckman, 1976; Heckman, 1979) and using four years of pooled budget survey data: 1999, 2000, 2001 and 2002. Predicted wages were used in the estimation of the labour supply model only for households where one or both partners were out of employment.

Estimates of the wage equations are presented in Table 7-1. The signs of most coefficients are as expected and correspond to what is found in other studies (e.g. Orsini, 2008). We also observe a selection bias that is more pronounced for females than for males which is consistent with what is found in other countries (Choudhuri, 1993).

\subsubsection{Estimation of the labour supply model}

The parameter estimates of the labour supply model for couples, single females, and single males, corresponding to equations (1.3) and (1.4), are shown in Table 7-2, Table 7-3, and Table 7-4 respectively. 
TABLE 7-1 WAGE EQUATION FOR FEMALES AND MALES (MAXIMUM LIKELIHOOD HECKMAN CORRECTION) ${ }^{1}$

\begin{tabular}{|c|c|c|c|c|c|c|}
\hline & \multicolumn{3}{|c|}{ Females } & \multicolumn{3}{|c|}{ Males } \\
\hline & Coeff. & Std. Err. & & Coeff. & Std. Err. & \\
\hline \multicolumn{7}{|l|}{ hourly wage rate $(\ln )$} \\
\hline primary education & 0.081 & 0.041 & * & 0.046 & 0.035 & \\
\hline lower secondary education & 0.265 & 0.037 & $* * *$ & 0.185 & 0.032 & *** \\
\hline higher secondary education & 0.502 & 0.038 & $* * *$ & 0.337 & 0.033 & $* * *$ \\
\hline higher non-university education & 0.788 & 0.039 & *** & 0.561 & 0.034 & *** \\
\hline university education & 0.966 & 0.042 & $* * *$ & 0.783 & 0.035 & *** \\
\hline potential experience $^{2}$ & 0.433 & 0.019 & *** & 0.324 & 0.023 & *** \\
\hline potential experience squared ${ }^{2}$ & -0.078 & 0.004 & $* * *$ & -0.037 & 0.005 & *** \\
\hline living in Flanders & -0.031 & 0.014 & ** & -0.056 & 0.015 & *** \\
\hline living in Brussels & 0.009 & 0.012 & & -0.027 & 0.014 & * \\
\hline observed in budget survey 2000 & -0.170 & 0.017 & *** & -0.141 & 0.014 & *** \\
\hline observed in budget survey 2001 & -0.163 & 0.017 & $* * *$ & -0.164 & 0.014 & $* * *$ \\
\hline observed in budget survey 2002 & -0.148 & 0.017 & $* * *$ & -0.102 & 0.015 & *** \\
\hline constant & 1.384 & 0.043 & *** & 1.822 & 0.044 & *** \\
\hline \multicolumn{7}{|c|}{ selection equation: employment ( $1=$ in employment) } \\
\hline observed in budget survey 2000 & -0.319 & 0.041 & $* * *$ & -0.130 & 0.057 & ** \\
\hline observed in budget survey 2001 & -0.314 & 0.042 & *** & -0.107 & 0.059 & * \\
\hline observed in budget survey 2002 & -0.373 & 0.042 & *** & -0.199 & 0.058 & *** \\
\hline partner works (1=yes) & -0.032 & 0.024 & & 0.535 & 0.044 & $* * *$ \\
\hline number of children under 3 & -0.189 & 0.040 & $* * *$ & 0.348 & 0.084 & *** \\
\hline number of children between 3 and 6 & -0.158 & 0.037 & $* * *$ & 0.241 & 0.080 & $* * *$ \\
\hline age & 1.949 & 0.096 & $* * *$ & 3.090 & 0.129 & $* * *$ \\
\hline age squared & -0.252 & 0.012 & *** & -0.351 & 0.016 & *** \\
\hline primary education & 0.328 & 0.080 & $* * *$ & 0.531 & 0.096 & *** \\
\hline lower secondary education & 0.659 & 0.071 & $* * *$ & 0.874 & 0.086 & $* * *$ \\
\hline higher secondary education & 1.060 & 0.069 & $* * *$ & 1.022 & 0.084 & *** \\
\hline higher non-university education & 1.465 & 0.073 & *** & 1.177 & 0.088 & *** \\
\hline university education & 1.579 & 0.082 & $* * *$ & 1.298 & 0.098 & *** \\
\hline constant & -3.762 & 0.200 & $* * *$ & -6.330 & 0.262 & $* * *$ \\
\hline rho & 0.915 & 0.008 & & -0.168 & 0.056 & \\
\hline sigma & 0.466 & 0.006 & & 0.392 & 0.004 & \\
\hline lambda & 0.426 & 0.008 & & -0.066 & 0.022 & \\
\hline Number of obs & & 8350 & & & 7577 & \\
\hline censored & & 2874 & & & 1119 & \\
\hline not censored & & 5476 & & & 6458 & \\
\hline Log-likelihood & & -6579.90 & & & -5588.11 & \\
\hline Wald Chi2 (12) & & 1932.43 & & & 1822.02 & \\
\hline LR test of independent equations & & 319.92 & & & 6.32 & \\
\hline
\end{tabular}

* significant at $10 \%$; ** significant at $5 \%$; *** significant at $1 \%$

${ }^{1}$ Females and males aged between 18 and 65 either employed, unemployed or inactive

2 Potential experience is defined as current age net of years of schooling and the age when schooling starts (6) 
TABLE 7-2 ESTIMATES OF PREFERENCE STRUCTURE: COUPLES

\begin{tabular}{|c|c|c|c|}
\hline & Coeff. & Std. Err. & \\
\hline Income & 4.366 & 0.815 & $* * *$ \\
\hline x Age female & -0.127 & 0.041 & $* * *$ \\
\hline$x$ Age female squared & 0.199 & 0.051 & $* * *$ \\
\hline x Age male & -0.015 & 0.022 & \\
\hline x Age male squared & -0.005 & 0.028 & \\
\hline$x$ Number of children & 0.028 & 0.056 & \\
\hline Income squared & 0.007 & 0.023 & \\
\hline Leisure male & -0.343 & 0.025 & *** \\
\hline x Age male & 0.011 & 0.001 & $* * *$ \\
\hline x Age male squared & -0.013 & 0.002 & *** \\
\hline $\mathrm{x}$ Number of children & 0.006 & 0.002 & $* * *$ \\
\hline Leisure male squared & 0.004 & 0.000 & *** \\
\hline Leisure female & -0.220 & 0.020 & *** \\
\hline x Age female & 0.012 & 0.001 & $* * *$ \\
\hline x Age female squared & -0.018 & 0.001 & *** \\
\hline$x$ Number of children $<=3$ years & -0.018 & 0.003 & $* * *$ \\
\hline$x$ Number of children $>3$ and $<=6$ years & -0.019 & 0.003 & *** \\
\hline$x$ Number of children $>6$ and $<=12$ years & -0.015 & 0.002 & $* * *$ \\
\hline$x$ Number of children $>12$ years & -0.010 & 0.002 & *** \\
\hline Leisure female squared & 0.000 & 0.000 & *** \\
\hline Income $x$ Leisure male & -0.015 & 0.003 & *** \\
\hline Income $x$ Leisure female & -0.014 & 0.002 & $* * *$ \\
\hline Leisure male $x$ Leisure female & 0.001 & 0.000 & *** \\
\hline Observations & \multicolumn{3}{|c|}{4827} \\
\hline Log-lokelihood & \multicolumn{3}{|c|}{-5988.21} \\
\hline Wald Chi2(5) & \multicolumn{3}{|c|}{34.76} \\
\hline
\end{tabular}

${ }^{*}$ significant at $10 \%$; ** significant at $5 \%$; significant at $1 \%$ 
TABLE 7-3 ESTIMATES OF PREFERENCE STRUCTURE: SINGLE FEMALES

\begin{tabular}{|c|c|c|c|}
\hline & Coeff. & Std. Err. & \\
\hline Income & 13.026 & 2.985 & $* * *$ \\
\hline x Age female & -0.334 & 0.140 & ** \\
\hline$x$ Age female squared & 0.389 & 0.159 & $* *$ \\
\hline$x$ Number of children & 0.287 & 0.151 & * \\
\hline Income squared & -0.201 & 0.137 & \\
\hline Leisure female & -0.225 & 0.056 & $* * *$ \\
\hline x Age female & 0.009 & 0.003 & $* * *$ \\
\hline$x$ Age female squared & -0.012 & 0.003 & $* * *$ \\
\hline$x$ Number of children $<=3$ years & -0.012 & 0.008 & \\
\hline$x$ Number of children $>3$ and $<=6$ years & -0.010 & 0.007 & \\
\hline$x$ Number of children $>6$ and $<=12$ years & -0.002 & 0.005 & \\
\hline$x$ Number of children $>12$ years & 0.016 & 0.005 & $* * *$ \\
\hline Leisure female squared & 0.003 & 0.000 & $* * *$ \\
\hline Income $x$ Leisure female & -0.094 & 0.012 & $* * *$ \\
\hline Observations & & 1896 & \\
\hline Log-lokelihood & & -1379.19 & \\
\hline Wald Chi2(3) & & 7.68 & \\
\hline
\end{tabular}

TABLE 7-4 Estimates OF PREFERENCE STRUCTURE: SINGLE MALES

\begin{tabular}{|c|c|c|c|}
\hline & Coeff. & Std. Err. & \\
\hline Income & 8.772 & 2.973 & $* * *$ \\
\hline x Age male & -0.233 & 0.135 & * \\
\hline x Age male squared & 0.232 & 0.149 & \\
\hline Income squared & 0.268 & 0.066 & $* * *$ \\
\hline Leisure male & -0.278 & 0.056 & $* * *$ \\
\hline x Age male & 0.009 & 0.003 & $* * *$ \\
\hline $\mathrm{x}$ Age male squared & -0.012 & 0.003 & $* * *$ \\
\hline x Number of children & 0.011 & 0.004 & $* * *$ \\
\hline Leisure male squared & 0.004 & 0.000 & $* * *$ \\
\hline Income $x$ Leisure male & -0.068 & 0.007 & $* * *$ \\
\hline Observations & & 1699 & \\
\hline Log-lokelihood & & -1096.94 & \\
\hline Wald Chi2(5) & & 4.34 & \\
\hline
\end{tabular}

* significant at $10 \%$; ** significant at $5 \%$; significant at $1 \%$

\subsubsection{Model calibration and labour supply responses}

In this subsection, we briefly describe how labour supply responses and revenue effects shown in the main text were arrived at. 
The estimation of the model explained in the previous section allows to determine the deterministic part of the utility function in (1.1) for each possible labour supply choice. The next step is to replicate observed labour supply in the baseline scenario by adding to the deterministic part a random term such that the actually observed number of hours worked is also the optimal choice predicted by the model, i.e. provides the highest utility.

This calibration consists in drawing sets of random utility terms $\varepsilon_{i j}$ from the relevant distribution (extreme value), one for each combination of hours worked (maximum 9 for couples in our case). For each potential choice of labour supply the random term is then added to the deterministic part of utility corresponding to that choice. The labour supply predicted by the model is the one having the highest calculated (stochastic) utility (deterministic part plus random utility part). If the predicted choice corresponds to the observed one the corresponding heterogeneity term $\varepsilon_{i j}$ is retained. The process continues until a random utility term is found for each observation that makes the preferred choice predicted by the model correspond to the observed one. These steps are repeated 100 times resulting in 100 heterogeneity terms for each observation (one heterogeneity term for each run of the loop that makes the predicted choice in that run correspond to the observed one).

To determine labour supply responses, we calculate the deterministic part of the utility function in (1.1) for every possible labour supply choice in each of the reform situations (different flat tax rates resulting in different disposable incomes). We again loop a 100 times and at each run and for each reform scenario we determine the utility for all possible labour supply choices by adding to the respective deterministic utility parts the random utility term, found in the corresponding run of the calibration step. The stochastic utilities, the $V_{i j}{ }^{\prime}$ s, are compared across the different combinations of hours worked and the predicted choice is the one that results in maximum utility.

The end result are 100 predictions of labour supply for each individual and for each reform scenario. From this, probabilities can be derived by dividing by 100 the number of times a certain hours combination is predicted by the model. These probabilities are then used to estimate all the results with flexible labour supply for different flat tax scenarios shown in the text, e.g. personal income taxes for a single female in a reform scenario with a flat tax rate of $37 \%$ are obtained by a weighted average of personal income taxes due were she to work 0,20 , or 40 hours while facing a tax rate of $37 \%$, the weights being the probabilities of choosing that particular number of hours.

\subsection{THE COST RECOVERY EFFECT WITH A NON REVENUE NEUTRAL FLAT TAX}

In Table 11 we present estimates of the cost recovery effect, as it is often used in public discussion. In the second row of the table we give the initial cost of a chosen flat tax rate in a scenario with fixed labour supply, unchanged consumption and excluding 
government spending on social assistance. This is compared in the line below with the revenue of this same tax rate after labour supply adjustments have been taken into account as well as changes in indirect tax revenue. The difference between the two is the cost recovery in absolute terms (in millions of $€$ ). Relating this absolute cost recovery to very different initial costs evidently shows up in percentage cost recoveries that are not comparable. Speaking about cost recovery in percentage terms only makes sense when comparing tax reforms that have the same initial impact on the budget.

TABLE 11: COST RECOVERY FOR DIFFERENT FLAT TAXES (IN MILLION $€$ AND IN \% OF THE INITIAL COST)

\begin{tabular}{lccccccc}
\hline & \multicolumn{7}{c}{ Net revenue in baseline (2005): €80,058 million } \\
\hline & 25 & 30 & 35 & 36 & 37 & 38 & 39 \\
\hline $\begin{array}{l}\text { net revenue, no } \\
\text { behavioral adjustment }\end{array}$ & 66,570 & 71,575 & 76,579 & 77,580 & 78,580 & 79,581 & 80,582 \\
$\begin{array}{l}\text { initial cost (mio } € \text { ) } \\
\text { net revenue, after }\end{array}$ & $-13,488$ & $-8,483$ & $-3,479$ & $-2,478$ & $-1,478$ & -477 & 524 \\
behavioral adjustment & 70,376 & 74,501 & 78,582 & 79,395 & 80,191 & 81,002 & 81,802 \\
final cost (mio $€$ ) & $-9,682$ & $-5,557$ & $-1,476$ & -663 & 133 & 944 & 1,744 \\
cost recovery (mio $€$ ) & 3,806 & 2,926 & 2,003 & 1,815 & 1,611 & 1,421 & 1,220 \\
$\begin{array}{l}\text { cost recovery in \% of } \\
\text { initial cost }\end{array}$ & 28.2 & 34.5 & 57.6 & 73.2 & 109.0 & 297.9 & -232.8 \\
\hline
\end{tabular}




\section{References}

Aaberge R., Colombino U., Strøm S. and Wennemo T. (1998), Evaluating alternative tax reforms in Italy with a model of joint labor supply of married couples, Structural Change and Economic Dynamics, 9(4), 415-433.

Adam, S. and Browne, J. (2006), Options for a UK 'flat tax'. Some simple simulations, IFS Briefing Note $\mathrm{N}^{\circ}$. 72, Institute for Fiscal Studies, London.

Altig D., Auerbach A., Kotlikoff L.J., Smetters K.A., and Walliser J. (2001), Simulating fundamental tax reform in the United States, American Economic Review, 91(3), 574-595.

Bargain O., Caliendo M., Haan P. and Orsini K. (2005), 'Making Work Pay' in a rationed labour market: the Mini-Job reform in Germany, DIW Working Paper 536.

Blundell, R., Duncan, A., McCrae, J., and Meghir, C., (2000), The labour market impact of the Working Families Tax Credit, Fiscal Studies, 21, 75-104.

Capéau, B., Decoster, A., De Swerdt, K., and Orsini, K. (2008), Welfare effects of alternative financing of social security. Some calculations for Belgium, Discussion Paper DPS 08.12, Center for Economic Studies, Leuven.

Choudhuri, C., (1993), Reassessing the male-female wage differential: a fixed effects approach, Southern Economic Journal, 60, 327-340.

Davies J. and Hoy M. (2002), Flat rate taxes and inequality measurement, Journal of Public Economics, 84(1), 33-46.

Decoster A. en Van Camp G. (2005), Hoe vlaks is onze tax? Is een flat tax "fair"?, Leuvense Economische Standpunten 2005/110, Centrum voor Economische Studiën, KULeuven.

Decoster, A., De Rock, B., De Swerdt, K., Flannery, D., Loughrey, J., O'Donoghue, C., Verwerft, D., (2007), Matching indirect tax rates on budget surveys for five selected countries, AIM-AP deliverable WP 3.3, available at: http://www.iser.essex.ac.uk/msu/emod/aim-ap/deliverables/

Decoster A., De Swerdt K., Orsini K, Lefèbvre M., Maréchal C., Paszukiewicz, Perelman S., Rombaut K. Verbist G, Van Camp G. (2008) Valorisation of the microsimulation model for social security MIMOSIS, Final Report of Project AG/01/116 of Federal Science Policy, available at: http:/ / socialsecurity.fgov.be/docs/nl/publicaties/mimosis/

Feldstein M. (1995), The Effect of Marginal Tax Rates on Taxable Income: A Panel Study of the 1986 Tax Reform Act, Journal of Political Economy, 103(3), 551-72.

Fuest C., Peichl A. and Schaefer T. (2008), Is a flat tax reform feasible in a grown-up democracy of Western Europe? A simulation study for Germany, International Tax and Public Finance, forthcoming.

Heckman, J., (1976), The common structure of statistical models of truncation, sample selection and limited dependent variables and a simple estimator for such models, Annals of Economic and Social Measurements, 5, 475-492.

Heckman, J., (1979), Sample specification bias as a selection error, Econometrica, 47, 153162. 
Ivanova A., Keen M. and Klemm A. (2005), The Russian Flat Tax Reform, Economic Policy, 20 (43), p. 1093-1118.

Jacobs B., de Mooij R. and Folmer K. (2007), Analyzing a Flat Income Tax in the Netherlands, Tinbergen Institute Discussion Paper, TI 2007-029/3.

McFadden, D., (1974), Conditional logit analysis of qualitative choice behaviour, in Zarembka, P., ed., Frontiers in Econometrics, Academic Press, New York.

Orsini K. (2006a), Is Belgium 'Making Work Pay'?, Centrum voor Economische Studiën, Leuven, Discussion Paper DPS 06.05.

Orsini K. (2006b), Tax-benefit reforms and the labor market: evidence from Belgium and other EU countries, Centrum voor Economische Studiën, Leuven, Discussion Paper DPS 06.06 .

Orsini K. (2008), Making Work Pay: Insights from Microsimulation and Random Utility Models, PhD Faculty of Business and Economics KULeuven nr275.

Paulus, A. and Peichl, A. (2008), Effects of Flat Tax Reforms in Western Europe on Equity and Efficiency, FiFo-CPE Discussion Paper No. 08-4;

Standaert I. and Valenduc C. (1996), Het Microsimulatiemodel van de Personenbelasting in België: SIRe, Studie- en Documentatiedienst van het Ministerie van Financiën, Research Paper no 1.

Sutherland H., (2001), Final report EUROMOD: an integrated European benefit-tax model, EUROMOD working paper EM9/01.

Valenduc, C. (2006), Une flat tax en Belgique? Quelques éclairages sur les principes et les conséquences d'une telle réforme, Reflets et Perspectives de la Vie Economique, 45 (3), p. 63-80.

Van Soest, A., (1995), Structural models of family labour supply: a discrete choice approach, Journal of human resources, 30, 63-88.

Ventura G. (1999), Flat tax reform: A quantitative exploration, Journal of Economic Dynamics and Control, 23(9-10), 1425-1458. 